\title{
BRITISH COOPERATIVE CLINICAL GROUP
}

The Council of the Medical Society for the Study of Venereal Diseases proposed the formation of a British Cooperative Clinical Group for the immediate purpose of collecting information concerning the venereal diseases from case records available in this country. A Committee consisting of $\mathrm{Mr}$. A. J. King (Chairman), Col. L. W. Harrison, Dr. R. Lees, Dr. G. L. M. McElligott, Dr. W. V. MacFarlane, Dr. A. E. W. McLachlan, Dr. Mary Michael Shaw, Dr. A. E. Wilkinson, and Dr. R. R. Willcox (Secretary) was appointed to consider plans for the formation of the organization, and held meetings in London on April 27, 1951, at 11 Chandos Street, W.1, and on June 1, 1951, at St. Mary's Hospital Medical School, Paddington, W.2.

The Committee wrote to all medical officers in charge of clinics in Great Britain, and 94 of them expressed their willingness to join in the activities of the Group. Dr. Guthe of the World Health Organization, who was asked to suggest a line of study which would contribute information of value to the organizations concerned with the international control of the venereal diseases, replied that a study of the effects of methods of intensive treatment of early syphilis would be the most valuable.

The Committee presented a report of its activities to the Medical Society for the Study of Venereal Diseases at the Annual General Meeting on June 27, 1951. The Society approved the formation of the Group and made a grant of $£ 100$ for expenses. The following regional representatives were elected :

$\begin{array}{ll}\text { London West : } & \text { Dr. G. L. M. McElligott } \\ \text { London East : } & \text { Mr. A. J. King } \\ \text { England South : } & \text { Dr. R. Warren } \\ \text { England West : } & \text { Dr. A. E. W. McLachlan } \\ \text { England Midlands : } & \text { Dr. E. W. Assinder } \\ & \text { Dr. R. Marinkovitch } \\ \text { England North : } & \text { Dr. D. J. Campbell } \\ & \text { Dr. R. Lees } \\ & \text { Dr. A. O. F. Ross } \\ & \text { Dr. W. V. MacFarlane } \\ \text { Wales : } & \text { Dr. C. C. R. Downing } \\ \text { Scotland : } & \text { Dr. R. C. L. Batchelor } \\ & \text { Dr. M. Moffet }\end{array}$

Drs W. N. Mascall and F. R. Curtis (Secretary and Assistant Secretary of the M.S.S.V.D.), Dr. M. Michael Shaw (President of the M.S.S.V.D.), Col. L. W. Harrison, and Dr. R. R. Willcox, were also elected. Dr. I. N. O. Price and Dr. A. E. Wilkinson were co-opted.

The Committee of the Cooperative Clinical Group has now held three meetings. At the first, held at 11 Chandos Street after the Annual General Meeting of the M.S.S.V.D., specimen case-cards which had been offered to the Group by the World Health Organization for collecting information for statistical purposes were examined, amended, and approved, and thanks were expressed to the WHO for its generosity in providing the cards.

At the second meeting, held at the Lock Hospital, W.1, on October 28, 1951, the following officers were elected :

\author{
Chairman : Mr. A. J. King. \\ Secretary: Dr. R. R. Willcox. \\ Treasurer: Dr. F. R. Curtis.
}

It was decided that the first investigation to be undertaken should concern the treatment of primary and secondary syphilis by all methods in the year 1946. Cards were later sent to the Regional Representatives for distribution to members for completion by March, 1952. A further suggestion by the World Health Organization that the properties of British penicillin preparations should be investigated was also closely examined. It was decided to approach the Ministry of Health to ascertain whether there were established arrangements whereby penicillin preparations could be tested and officially approved. Later, information became available that certain PAM preparations did not comply with the specifications of the World Health Organization. Mr. A. J. King, Dr. W. N. Mascall, and Dr. R. R. Willcox were invited to discuss this problem at a special meeting of the Therapeutic Trials Committee, convened by the Ministry of Health and attended by representatives of the manufacturers of penicillin and of the M.R.C.

At the third meeting, held at the Lock Hospital on February 29, 1952, it was resolved that no action should be taken in the matter of preparations of penicillin until the final results of the action taken by the Ministry were known. After receiving the representatives' reports on the completion of the cards for 1946, the Secretary was empowered to discuss with WHO in Geneva whether analysis of the data could be undertaken by their expert statisticians. It was decided that the investigation of the results of treatment of early syphilis in 1946 would be followed by further studies of primary and secondary syphilis treated in 1947 and after. Proposals for the plan of research into the results of current methods of treatment were made by Dr. F. R. Curtis and it was decided to consider these in detail at the next meeting. 